\title{
Resilience to climate change: from theory to practice through co- production of knowledge in Chile
}

\author{
Roxana Borquez $^{1,2}$ (1) Paulina Aldunce ${ }^{2,3} \cdot$ Carolina Adler $^{4}$
}

Received: 21 March 2016/Accepted: 14 September 2016/Published online: 3 October 2016

(C) The Author(s) 2016. This article is published with open access at Springerlink.com

\begin{abstract}
In theory, building resilience is touted as one way to deal with climate change impacts; however, in practice, there is a need to examine how contexts influence the capacity of building resilience. A participatory process was carried out through workshops in regions affected by drought in Chile in 2014. The aim was to explore how resilience theory can be better applied and articulated into practice vis-á-vis participatory approaches that enrich the research process through the incorporation of co-produced. The results show that there are more differences in responses by type of actor than between regions, where issues of national interest, such as 'education-information' and 'preparedness', are highlighted over others. However, historically relevant local topics emerged as differentiators:
\end{abstract}

Handled by Akhilesh Surjan, Charles Darwin University, Australia.

Roxana Borquez

roxana.borquez@kcl.ac.uk

Paulina Aldunce

paldunce@uchile.cl

Carolina Adler

carolina.adler@env.ethz.ch

1 Department of Geography, King's College London, Room K4.10, Fourth Floor, Strand Campus, London WC2R 2LS, UK

2 Center for Climate and Resilience Research (CR2), Blanco Encalada 2002, 4 Piso, DGF, Universidad de Chile, Santiago, Chile

3 Department of Environmental Science and Resource Management, Faculty of Agricultural Science, University of Chile, Santa Rosa 11.315, La Pintana, Santiago, Chile

4 Institute for Environmental Decisions and Transdisciplinarity Lab, D-USYS, ETH Zurich, CHN H 73.1, 16

Universitaetstrasse, 8092 Zurich, Switzerland decentralisation, and political will. This reinforces why special attention must be given to the different understandings in knowledge co-production processes. This study provides evidence and lessons on the importance of incorporating processes of the co-production of knowledge as a means to better articulate and transfer abstract concepts, such as resilience theory, into practice.

Keywords Co-production - Resilience - Climate change · Transdisciplinarity $\cdot$ Drought $\cdot$ Chile

\section{Introduction}

Climate change poses a great challenge to society, with urgent responses needed that contribute to building resilience and developing adaptation (Aldunce et al. 2016). However, building resilience first requires an understanding for the ways, in which the term is understood and articulated by diverse actors in a given situation. In resilience frameworks, key elements have been described for building resilience in the context of a changing climate. These emphasise the importance of participatory processes and the co-production of knowledge, and the participation of stakeholders and decision makers, but with a little grounded validation. The purpose of this study was to address this gap, exploring how resilience theory can be applied and articulated into practice through the participatory approaches as a means to incorporate and 'co-produce' knowledge.

A number of arguments support the idea that expanding the participation of actors for the co-production of knowledge is valuable for sustaining resilience. For example, diversity in group composition is considered important, where participation from a diverse range of 
views or considerations for discussion is emphasised (Aldunce et al. 2016; Berkes 2007; Folke 2006; Gero et al. 2011). Others orient this participation as a process where giving opportunities to share knowledge and expertise are important, recognising that all knowledge are relevant (Armitage et al. 2008; O'Brien et al. 2010; Thomalla and Larsen 2010), or in providing space to meet different needs and enabling learning and changing actions (Wildavsky 1988).

Given the scale and complexity of building resilience to climate change, responses require active participation from governments, citizens, scientists, and private sectors. Nevertheless, several critiques have emerged with regard to the role that these different actors play in this participation, as for example, the role of scientists. Scientists have generated theoretical frameworks on many subjects related to climate change in order to understand and parameterise its effects, as well as people/community responses to climate change (Berrang-Ford et al. 2011; Djalante and Thomalla 2010). However, among scientists, it has accomplished little agreement on how adaptation or resilience is built, analysed, and applied in practice, incorporating different criteria and methodologies (Berrang-Ford et al. 2011; Vogel et al. 2007).

The science-society relationship has been often understood as mainly unidirectional, where academia provides research and knowledge in return for public funds (Gibbons 1999), where communities are viewed as subjects of inquiry without asking them about key issues that allow them as communities to adapt or to be resilient (Aldunce et al. 2014a; Vogel et al. 2007; Warburton and Martin 1999). Nonetheless, a growing number of scientists are looking towards "the opening up of knowledge systems", enhancing relationships and collaboration between science and other actors, and orienting academic practice toward society (Cornell et al. 2013, p. 61).

On the whole, integrated research accounts for the complexity inherent in real-world problems (Miller et al. 2008; Cornell et al. 2013; Pohl et al. 2010), by integrating diverse knowledge systems in the process of co-producing knowledge. These knowledge systems should not only be understood as a collection of facts, but also as diverse ways, in which people understand, interpret, and give meaning to the world based on their experiences (Blaikie et al. 1997; Warburton and Martin 1999). In this paper, our goal is to complement knowledge on how to build resilience by demonstrating with case-based evidence how theory can be articulated into practice, how knowledge coproduction can enrich the research process between context, regions, and actors, and how participant inputs can be explained/contextualised. The findings are based on the results of workshops on building resilience to climate change which took place in three regions in Chile during 2014.

This paper is organised into four sections. In "Introduction", we summarise key literature that has guided this research and contextualise the case study. "Resilience: moving from theory to practice through co-production of knpwledge" details the research design and methodology used. In "Context of application", we present the results and discuss how these results inter-relate to each of the communities where we conducted these workshops as well as present an overarching analysis of what these results mean in the context of bringing theory to practice. Finally, we conclude "Materials and methods" with reflections, lessons, suggestions, and challenges for moving forward on the topic.

\section{Resilience: moving from theory to practice through co-production of knowledge}

The resilience perspective has influenced many disciplines and fields of research, including climate change (Maxwell 2009; Pelling 2011; Vogel et al. 2007; Walker and Salt 2006; Adler et al. 2015). However, there is no unique resilience framework, and its definition varies across different disciplines (Aldunce et al. 2015; Downes et al. 2013; Nelson et al. 2007). Literature on resilience specific to climate change includes a wide range of definitions and characteristics of resilience building (Aldunce et al. 2014a). According to Brandt et al. (2013), this diversity in conceptualisations is considered a weakness of the approach. However, we argue instead that this diversity is positive, because it gives flexibility which can be applied to different contexts and is part of the complexity inherent in the real world. Moreover, we believe that this diversity can be addressed through the transdisciplinary approaches that account for this complexity, because resilience cannot be reduced or simplified to one single perspective.

From a transdisciplinary perspective, moving from theory to practice through the co-production of knowledge involves the development of "empirical and practice-oriented knowledge than can help solve, mitigate or prevent life-world problems" (Pohl and Hirsch Hadorn 2007, p. 26). Thus, based on the conceptualization that "knowledge is a precondition for learning", co-production of knowledge can be seen as a mechanism which enables learning, where five process dimensions play a role: "(1) knowledge gathering, (2) knowledge sharing, (3) knowledge integration, (4) knowledge interpretation, and (5) knowledge application" (Armitage et al. 2011, p. 998). Consequently, this type of research addresses socially relevant problems through "contextualised knowledge", a concept coined by Gibbons (1999, C82) to explain the 
Table 1 Regional summary Sources: INE (2010), INE (2012), INE (2014), BCN (2016), Ilustre Municipalidad de Valdivia (2016)

\begin{tabular}{|c|c|c|c|c|c|}
\hline Region & Climate & $\begin{array}{l}\text { Average of annual precipitation } \\
(\mathrm{mm})\end{array}$ & $\begin{array}{l}\text { Population density } \\
\text { (inhabitants } / \mathrm{km}^{2} \text { ) }\end{array}$ & $\begin{array}{l}\text { Main economic } \\
\text { activities }\end{array}$ & $\begin{array}{l}\text { Rural population } \\
(\%)\end{array}$ \\
\hline Los Ríos & $\begin{array}{c}\text { Temperate } \\
\text { oceanic }\end{array}$ & $1200-5500$ & 21.8 & Business & 31.4 \\
\hline Biobío & Mediterranean & $1200-2000$ & 56.7 & Forestry & 16.3 \\
\hline Metropolitana & Mediterranean & 356.2 & 469.3 & Forestry agriculture & 3.4 \\
\hline
\end{tabular}

outcome of a mutual transformation between science and society. This includes reverse communication flows, where scientists seek socially robust knowledge, beyond scientific certainty, recognising that changes involve a complex interaction and feedback into socio-ecological systems over temporal and spatial scales (Gibbons 1999; Cornell et al. 2013).

In the context of our study, we applied a participatory methodology that included the delivery of information to participants. This information was the results of a systematic literature review on resilience to climate change for articles published between 2000 and 2012, where 15 determinants and 33 attributes were identified for resilience (for a detail description of determinants and attributes, see Aldunce et al. (2014b)), and factual data on drought in each region. This information was the starting point of the workshops. Thus, academic, social, private, and public actors jointly analysed that which aspects of the theory are relevant for their resilience building. Furthermore, scale and context were considered, recognising the contextspecific uniqueness and mutual-influence between global and local scales (Olwig 2012).

\section{Context of application}

Context is important for addressing the problem and the solutions proposed to address them, because cultural differences can influence perception, selection of options, interest, and meaning (Gibbons 1999; Wolf and Moser 2011). Thus, territorial aspect, multi-level governance, and climate drivers in the Chilean context were considered.

We carried out workshops in three Chilean regions: Los Ríos (Región de Los Ríos), Biobío (Región del Biobio), and Metropolitan (Región Metropolitana de Santiago). These three regions have distinct bio-physical, social, and economic conditions that can influence diverse responses to climate change (see Table 1). Figure 1 shows the geographical location of regions.

Chile has a diverse climate and topography, where precipitation deficit counts as one of the most important effects of climate change in this country (Meza et al. 2010). For these reasons, our study focused on drought as

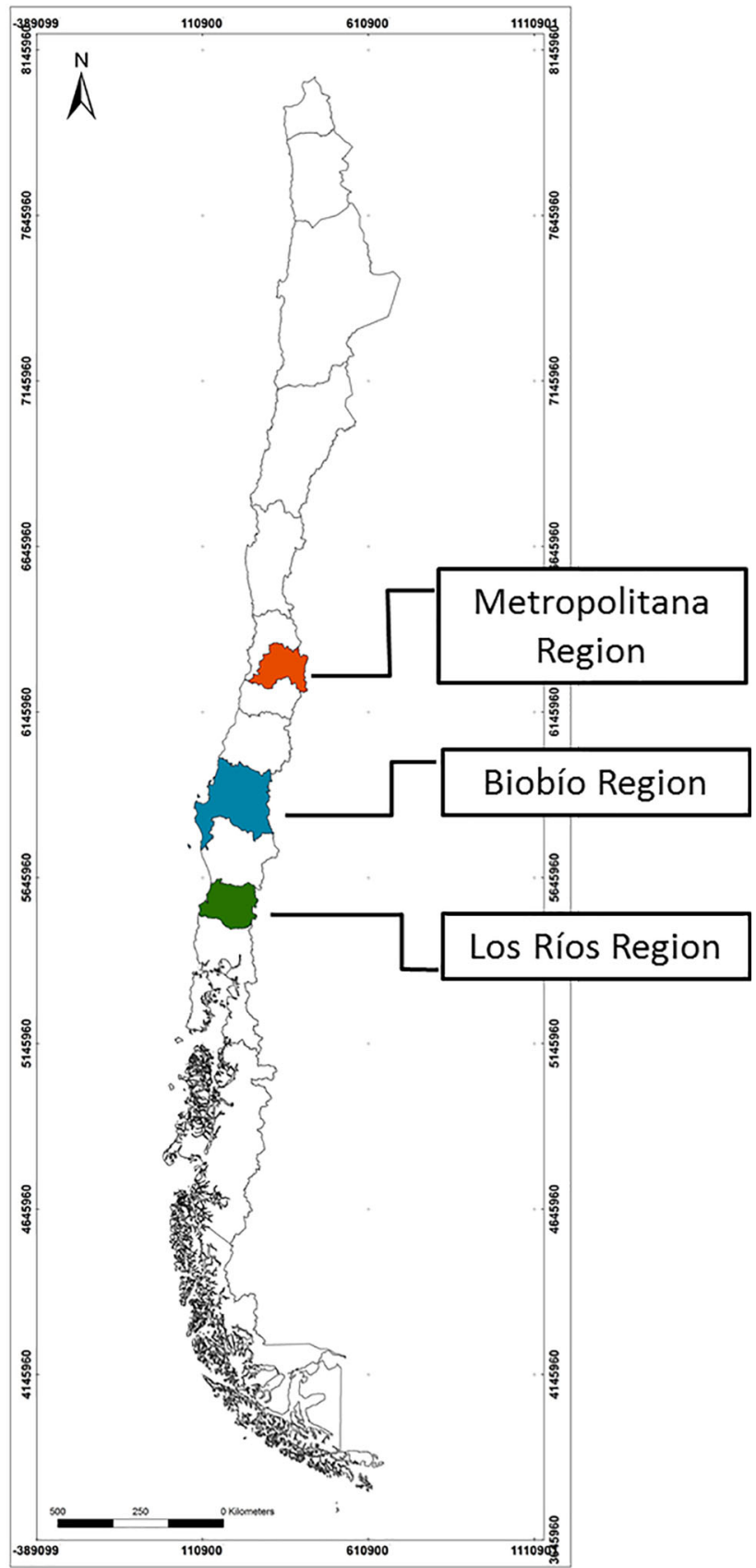

Fig. 1 Geographical location of regions where workshops were developed 
characterised by its slow onset, gradual impacts, cumulative effects, and conditional sensitivity to the context, in which it manifests. Therefore, it is important to highlight different effects that drought has on lifestyles, productive systems, and ecosystems due to the dependency to rainfall and/or water flows in the basis (freshwater, irrigation, energy production, and others) in different regions of Chile (Meza et al. 2010). According to Garreaud (2011), the projected changes in Chile between 2070 and 2100 (under A2 scenario-worst case-, using the PRECIS-DGF model) show that precipitations on Los Ríos and Biobío Region would decline strongly (a reduction of 60-70\% from the climatic baseline 1960-1990), and in Metropolitan region, precipitations would decrease between 15 and $30 \%$.

\section{Materials and methods}

Study phases and activities are shown in Table 2. The main framework of this study was based on the previous research developed by Aldunce et al. (2014b), where a systematic literature review of climate change resilience concept was performed for articles published between 2000 and $2012 .{ }^{1}$ As a starting point for input into our workshops, we used the identified 15 determinants and 33 attributes defined for resilience (Table 2).

Three data collection instruments were used during the workshops: two individual questionnaires and discussion groups.

Based on a project protocol, each workshop was designed in seven consecutive phases:

1. The initial questionnaire on resilience [first instrument part (a)] was completed by participants before the start of each workshop. This questionnaire sought to explore their level of knowledge of resilience.

2. Introduction (including workshop objectives, the study process, its strengths, limitations, and scope, who were the participants, why they were invited and why they were important in the process) and a presentation on drought in Chile, trends, and impacts (contextualization).

3. Presentation on study developed by Aldunce et al. (2014b).

4. Individual questionnaire of attributes (second instrument): each participant chose 10 of 33 attributes identified by Aldunce et al. (2014b). This questionnaire aimed to identify the individual preferences of attributes of climate change resilience.

\footnotetext{
1 Working paper available in: http://www.cr2.cl/wp-content/uploads/ 2016/06/Aldunce-et-al-2014-Working-paper-Conceptualization-Resi lience.pdf.
}

5. Discussion groups (third instrument): three discussion groups, each with a facilitator, were established in each workshop. The discussion section was divided into three parts: (1) the impacts of drought in each region; (2) the attributes of climate change resilience in their regional context; and (3) the characteristics of attributes and the roles of actor for building resilience communities.

This paper focuses in the two questionnaires and the second discussion (2), where after the completion of the individual questionnaire on attributes (second instrument), each participant, supported by graphic material, chose the five most important attributes in the drought context, where all participants could see these new selections. The aim was to determine how the individual preferences changed after a dialogue with other participants.

6. Plenary: each group explained its results.

7. Final questionnaire on resilience [first instrument part (b)]: each participant filled the same initial questionnaire; this allowed us to trace the learning gained by participants during the workshop.

Participants were actors dealing with drought in some way, according to their experience with the problem. For instance, actors were selected on the basis of their experience with drought, as people directly affected by it (i.e., experienced a direct or indirect losses as a result of drought), as planners, planning, and managing impacts of drought, or as scholars, studying the phenomenon. The identification of actors was carried out taking an account of the territorial and governance contexts. Actors included were from government agencies, the academic sector, civil society organisations, and the private sector (individual questionnaires were anonymous; however, participants were able to indicate what kind of actors they identify with).

The three workshops were carried out in June 2014, plus an open seminar developed in September 2014, where results were presented. The data analysis included a thematic analysis of resilience definitions (Boyatzis 1998), through a deconstruction of definitions given by participants in the first instrument, and a descriptive statistic of frequency (Mackey and Gass 2015), allowing us to rank occurrences of each response.

Eight main principles guided the work in order to ensure the suitable participation of all actors (see Table 3). They were the basis of the research design, of the invitation process and of the workshops in order to sensitise to the participants (facilitators were prepared for contemplating it). The differences between the scientific and local knowledge were a special concern, related to classification, identification, and conceptualization of natural phenomena, 
Table 2 Phases and activities of study Source: drawn from example by (Singh et al. 2012) and (Singh et al. 2013b)

\begin{tabular}{|c|c|c|c|}
\hline Phases & Period & Activities & Details \\
\hline \multirow[t]{3}{*}{ Preparatory } & $\begin{array}{l}\text { Jan-Dec } \\
2013\end{array}$ & $\begin{array}{l}\text { Systematic literature review } \\
\text { (Aldunce et al. 2014b) }\end{array}$ & Articles published on resilence to climate change, between 2000-2012. Scopus \\
\hline & $\begin{array}{l}\text { Jan-Apr } \\
2014\end{array}$ & $\begin{array}{l}\text { Methodological design } \\
\text { Objectives } \\
\text { Principles and protocol } \\
\text { Instruments } \\
\text { Identification of target groups } \\
\text { Selection of participants } \\
\text { Facilitator Guide and training } \\
\text { Material preparation }\end{array}$ & $\begin{array}{l}\text { Collaboration of researchers from: } \\
\text { Institute for environmental decision. ETH Zurich } \\
\text { Stockholm resilience center } \\
\text { Center for climate and resilience research, Chile }\end{array}$ \\
\hline & $\begin{array}{l}\text { May } \\
2014\end{array}$ & $\begin{array}{l}\text { Invitation and confirmation of } \\
\text { participants } \\
\text { Sending invitationsvia email } \\
\text { Calling to participants } \\
\text { Remenbering invitation, place } \\
\text { and time }\end{array}$ & 289 invitations sent \\
\hline Field work & Jun 2014 & $\begin{array}{l}\text { Workshops } \\
\text { Valdivia, Los Ríos Region. June } \\
3 . \\
\text { Concepcion, Biobío Region. } \\
\text { June } 4 . \\
\text { Santiago, Metropolitana Region. } \\
\text { June 11. }\end{array}$ & 61 participants \\
\hline Analytical & $\begin{array}{l}\text { Jun-Aug } \\
2014\end{array}$ & $\begin{array}{l}\text { Analysis of instruments } \\
\text { Thematic analysis (QSR Nvivo } \\
\text { 10) } \\
\text { Descriptive statistical of } \\
\text { frequency }\end{array}$ & $\begin{array}{l}\text { Individual questionnaire onResilience part A and B } \\
\text { Individual questionnaire on attributes } \\
\text { Wheel and transcription of discussion on attributes }\end{array}$ \\
\hline Informative & Sep 2014 & Seminar for returning results & $\begin{array}{l}\text { Santiago: } 76 \text { participants. } \\
\text { Via straming.: } 21 \text { participants (from Chile: Concepcion, Santiago, Valdivia; from } \\
\text { other countries: Colombia, Brazil, Mexico) }\end{array}$ \\
\hline
\end{tabular}

Table 3 Guiding principles of research Sources: LaVeaux and Christopher (2009); Moodie (2010); Warburton and Martin (1999); Singh et al. (2013a)

\begin{tabular}{|c|c|}
\hline Principles & Authors \\
\hline (a) Acknowledge the relevance of community experiences & LaVeaux and Christopher (2009) \\
\hline \multicolumn{2}{|l|}{ (b) Recognise the importance of each type of actor in the process } \\
\hline \multirow[t]{2}{*}{ (c) Respect different understanding and description of phenomena } & Warburton and Martin (1999) \\
\hline & LaVeaux and Christopher (2009) \\
\hline (d) Facilitate collaboration between participants all the process & Moodie (2010) \\
\hline (e) Inform strengths, limitations and scope of the process in order to reduce false expectations & Singh et al. $(2013 \mathrm{a}, \mathrm{b})$ \\
\hline (f) Promote a mutual learning & Moodie (2010) \\
\hline (g) Disseminate results and knowledge & Moodie (2010) \\
\hline (h) "Interpret data within the cultural context" & LaVeaux and Christopher (2009), \\
\hline
\end{tabular}

and the contribution of the local knowledge transmission in this kind of processes, where socio-ecological system are highlighted (Warburton and Martin 1999; Singh et al. 2012). For this reason, the discussion phase emphasised these differences of understanding, enriching the dialogue on what the attributes mean.

Two main criteria were applied in the process: shared understanding and the need to recognise the existence of 
asymmetries of power. The first was addressed through plenaries at the end of each workshop where a joint discussion served as a way to validate that the knowledge coproduced was agreeable to the participants. The second was addressed through the work of facilitators who were trained for safeguarding respect among participant and to include all points of views. Facilitators followed the same protocol and guide.

\section{Results and discussion: understanding local and national contexts}

In this section, we present the results of the study and the discussion of the most relevant results and their implications for bringing resilience theory into practice. The section is divided into four parts: (1) distribution of participants by type of actors and territorial scale; (2) deconstruction of resilience; (3) attributes of resilience; and (4) general analysis.

\section{Distribution of participants}

The academic sector and government agencies represent over $80 \%$ of participants (Fig. 2). In Biobío and Metropolitan regions, there is no participation by the private sector, and civil society participation was less than one-tenth of participants. This was despite the broad invitation made to participate in the workshops, including a total of 289 invitations. The private sector had a participation rate of $6.7 \%$. In contrast, the academic sector had the highest participation rate $(42.9 \%)$. The total participation rate was $21.8 \%$.

The absence of private sector actors can be partially explained, because the perceptions of managers are that these kinds of processes require "expensive time investment with uncertain returns and at worst a risk to their perceived autonomy and independence" (Cash et al. 2003, p. 8090). On the other hand, the low level of participation from civil society can be due to a lack of "territorialisation" of policies on climate change in Latin America, a process in which a global phenomenon, such as climate change, is involved in local/regional territories and linked with local policies (Blanco and Fuenzalida 2013). In the Chilean case, a lack of territorialisation of policies on climate change is observed (Blanco and Fuenzalida 2013).

Related to territorial scale (Fig. 3), the distribution of government agencies was balanced between local, regional, and national levels. The low presence of provincial actors is explained by the fact that in Chile, the provincial government is an administrative level with less representation than national and municipal levels. Civil society was comprised of NGOs and local organisations. The presence of more NGOs than local organisations can be explained by the fact that the NGOs are formal institutions, with clear direction, projects, leadership, and employees. In contrast, local organisations are not necessarily formally constituted and participation is voluntary. This difference, alongside the low degree of territorialisation of policies reflecting local conditions, can influence the level of participation of local organisations. In the case of the academic sector in Chile, universities have regional representation. It was not possible to sub-divide the private sector into types of participants due to the low level of participation.

\section{Deconstruction of resilience}

The first instrument (questionnaire on resilience) asked 'what is resilience?' at the beginning and the end of each workshop. A vast majority (95.5\%) of respondents understood resilience as an ability or capacity. Answers were deconstructed into three parts: ability or capacity for (A) whom, meaning the identity that is resilient; resilience to what? (B); and in order to achieve something (C) (see Fig. 4), following analysis realised by Aldunce et al. (2014b). Table 4 shows responses, divided by region and by topic according to the definition given by each participant (the order of appearance is according to the most named).

In the initial questionnaire, half of the participants mentioned who is resilient: $39.4 \%$ indicated that a system is resilient and $8.6 \%$ indicated that individuals or organisms are resilient. Related to ability or capacity for 'A', there are no apparent important differences between regions. 'To recover' seems to be the most important verb associated with resilience (almost $50 \%$ of mentions), followed by 'to adapt' $(20.7 \%)$ and 'to resist' $(12.6 \%)$. This is consistent with responses related to 'in order to' (C), where 'to return to an initial state' obtained $60 \%$ of responses. The ideas about 'the capacity to recover' (A) and 'to return to an initial state' (C) were strongest in Biobío, where the former obtained a $74.1 \%$ and the latter obtained a $100 \%$ of mentions. In Biobío, these results could have been influenced by the earthquake in 2010 $(\mathrm{Mw}=8.8)$, where this region was epicentre, with major losses and destruction.

The general idea of resilience given by participants refers to the 'capacity' of a 'system' 'to recover' from 'disturbance' in order 'to return to an initial state'. It is interesting to observe that participants used verbs, such as 'to recover' and 'to return', concepts used mainly by disciplines in psychology and psychiatry to refer to individuals or human communities (Aldunce et al. 2014a).

Analysing by type of actor, it is interesting that definitions of public sector, civil society, and private sector included positive framing of resilience as the capacity for 


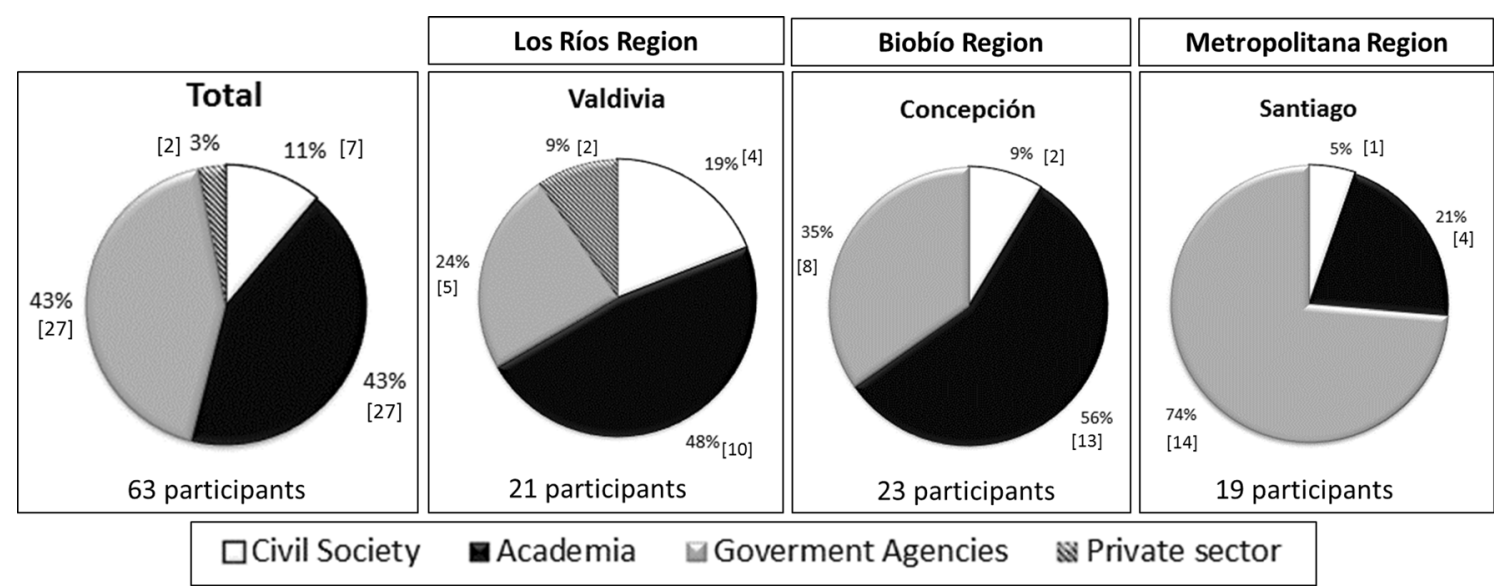

Fig. 2 Total participants in workshops and by region

Fig. 3 Distribution of government agencies and civil by territorial scale
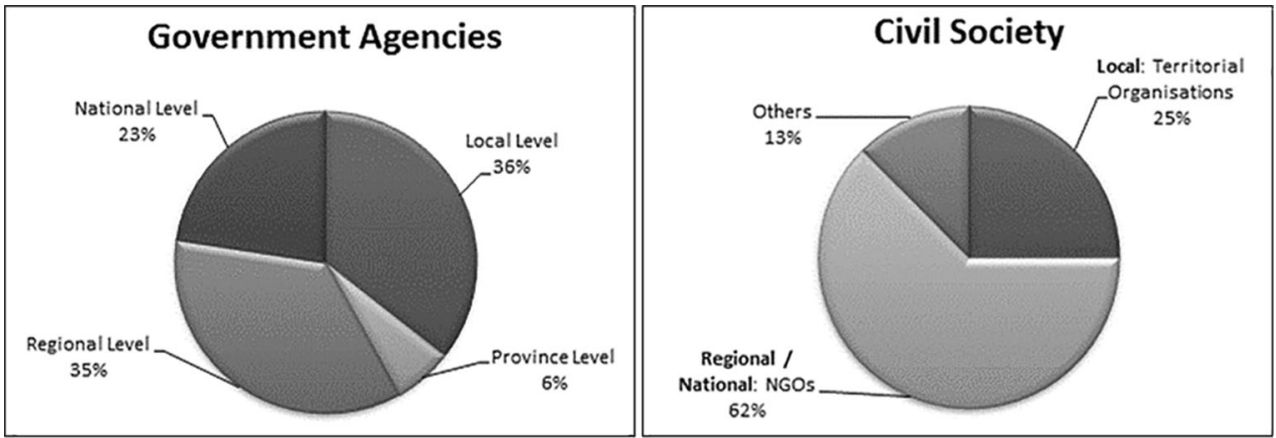

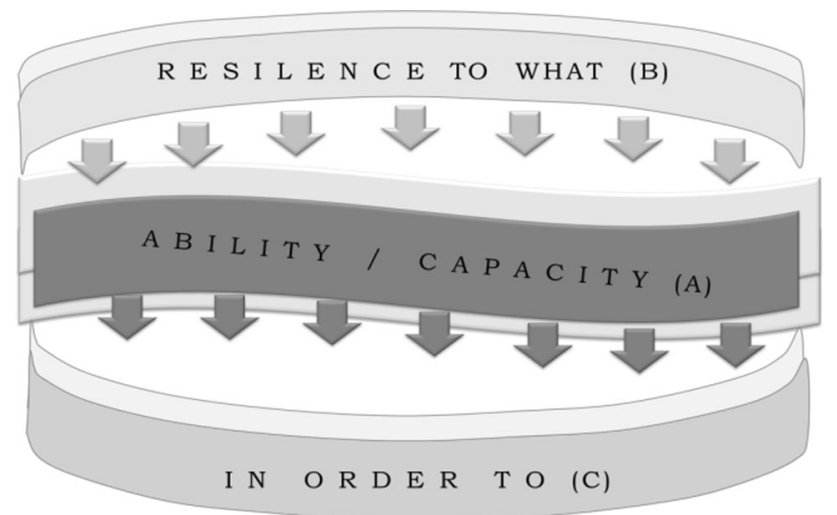

Fig. 4 Deconstruction of resilience definition Source: (Aldunce et al. 2014b)

'recovering' and 'adapting', and also 'to learn', 'to transform', and 'to re-organise', in the face of 'adverse contexts', 'change', or 'new context', where this new context is not necessarily negative. In contrast, the academic sector indicated only limited ideas of resilience as the capacity for 'recovering' to 'disturbance', 'change' and 'adverse context', associated mainly with negative expressions. Perhaps, this situation can be explained by the gap between science and society in Chile, according to Aldunce et al. (2014b), the inter-linkages between science and other actors have not been sufficiently fluid.

The same question was answered at the end of workshops. In the case of who is resilient, although 'no mentions' remained high, the 'socio-ecological system' emerged notably ( $64.3 \%$ of participants who included this topic). In the same vein, other concept emerged, passing of recovering towards adapting, and to return to an initial state towards maintaining functions. Related to 'resilience to what', responses are very similar to the initial questionnaire: adverse events and change, but new responses included climate change, absent in the first questionnaire. In addition, the diversity of response decreased in the final questionnaire.

This shows that results were influenced by participation in the workshops and presentations given. This should be understood as a process of learning, implicating a change in who learns (van de Kerkhof and Wieczorek 2005), and a shared/distributed understanding/cognition of meaning in concepts and terminology (Pahl-Wostl et al. 2007). Even, as Olwig (2012), p. 118 argues, "local resilience is thus the result of local and global imaginaries", where there is almost always an influence, which is necessary to recognise. An examination of this issue is analysed in the "General analysis" section. 
Table 4 Initial and final questionnaires

\begin{tabular}{|c|c|c|c|c|c|c|c|c|}
\hline \multirow[t]{2}{*}{ Region } & \multicolumn{2}{|l|}{ Whom? } & \multicolumn{2}{|c|}{ Ability/capacity (A) } & \multicolumn{2}{|l|}{ To what (B) } & \multicolumn{2}{|l|}{ In order to $(\mathrm{C})$} \\
\hline & Initial & Final & Initial & Final & Initial & Final & Initial & Final \\
\hline Los Ríos & $\begin{array}{l}\text { No mentions } \\
\text { System } \\
\text { Ecosystem } \\
\text { Socio-Ecosystem } \\
\text { Individual/ } \\
\text { organism } \\
\text { Social System }\end{array}$ & $\begin{array}{l}\text { No mentions } \\
\text { System } \\
\text { Socio- } \\
\text { Ecosystem }\end{array}$ & $\begin{array}{l}\text { To } \\
\text { recover } \\
\text { To adapt } \\
\text { To resist }\end{array}$ & $\begin{array}{l}\text { To adapt } \\
\text { To } \\
\text { respond }\end{array}$ & $\begin{array}{l}\text { Disturbance } \\
\text { Adverse } \\
\text { events }\end{array}$ & $\begin{array}{r}\text { Adverse } \\
\text { events }\end{array}$ & $\begin{array}{l}\text { To return to an initial } \\
\text { state }\end{array}$ & $\begin{array}{l}\text { To maintain } \\
\text { functions }\end{array}$ \\
\hline Biobío & $\begin{array}{l}\text { No mentions } \\
\text { System } \\
\text { Individual/ } \\
\quad \text { organism } \\
\text { Social System } \\
\text { Ecosystem } \\
\text { Socio-Ecosystem }\end{array}$ & $\begin{array}{l}\text { No mentions } \\
\text { Socio- } \\
\text { Ecosystem } \\
\text { System } \\
\text { Individual/ } \\
\text { organism }\end{array}$ & $\begin{array}{l}\text { To } \\
\text { recover } \\
\text { To resist }\end{array}$ & $\begin{array}{l}\text { To adapt } \\
\text { To } \\
\text { recover }\end{array}$ & $\begin{array}{l}\text { Disturbance } \\
\text { Adverse } \\
\text { events }\end{array}$ & $\begin{array}{l}\text { Adverse } \\
\text { events } \\
\text { Change }\end{array}$ & $\begin{array}{l}\text { To return to an initial } \\
\text { state }\end{array}$ & To endure \\
\hline Metropolitan & $\begin{array}{l}\text { No mentions } \\
\text { System } \\
\text { Social System } \\
\text { Ecosystem } \\
\text { Socio-Ecosystem } \\
\text { Individual/ } \\
\quad \text { organism }\end{array}$ & $\begin{array}{l}\text { No mentions } \\
\text { System } \\
\text { Socio- } \\
\text { Ecosystem } \\
\text { Social } \\
\text { System } \\
\text { Individual/ } \\
\text { organism }\end{array}$ & $\begin{array}{l}\text { To } \\
\text { recover } \\
\text { To adapt } \\
\text { To resist }\end{array}$ & $\begin{array}{l}\text { To adapt } \\
\text { To } \\
\text { respond }\end{array}$ & $\begin{array}{r}\text { Adverse } \\
\text { events } \\
\text { Change }\end{array}$ & Change & $\begin{array}{l}\text { To return to an initial } \\
\text { state } \\
\text { To maintain essential } \\
\text { characteristics }\end{array}$ & $\begin{array}{l}\text { To maintain } \\
\text { functions }\end{array}$ \\
\hline Total & $\begin{array}{l}\text { System } \\
\text { Social System } \\
\text { Socio-Ecosystem/ } \\
\text { Ecosystem }\end{array}$ & $\begin{array}{l}\text { Socio- } \\
\text { Ecosystem } \\
\text { System }\end{array}$ & $\begin{array}{l}\text { To } \\
\text { recover } \\
\text { To adapt } \\
\text { To resist }\end{array}$ & $\begin{array}{l}\text { To adapt } \\
\text { To } \\
\text { recover } \\
\text { To } \\
\text { respond }\end{array}$ & $\begin{array}{l}\text { Disturbance } \\
\text { Adverse } \\
\text { events } \\
\text { Change }\end{array}$ & $\begin{array}{l}\text { Adverse } \\
\text { events } \\
\text { Change }\end{array}$ & $\begin{array}{l}\text { To return to an initial } \\
\text { state }\end{array}$ & $\begin{array}{l}\text { To maintain } \\
\text { functions } \\
\text { To endure }\end{array}$ \\
\hline
\end{tabular}

\section{Attributes of resilience}

In this questionnaire, each participant could choose 10 attributes which they considered important for resilience building to drought in their contexts. This selection considered attributes of social and ecological resilience, but this paper focus on social resilience. Figure 5 shows the selection of attributes by type of actors.

'Education-information', the most voted attribute, refers to "opportune, equitable and universal access to information and education" (Aldunce et al. 2014b, p. 18). It is necessary to consider two aspects related to education. First, this topic has emerged as a main attribute in other studies, for example, Olwig (2012) and (Aldunce et al. 2015), who studied local understandings of resilience in Ghana and Australia, respectively. Second, it is necessary to understand recent Chilean history. The major student movements since the return of democracy were developed in 2006 and 2011, changing the policy agenda and generating a massive demand for public education (Fleet 2011; Cabalin 2012). The influence of this movement on citizens was relevant: for example, according to national polls, $80 \%$ of the Chilean population supported the student movement (Cabalin 2012).

Preparedness was the second most mentioned attribute. Chile is exposed to a range of socio-natural and natural disasters, such as volcanic activity, earthquakes, tsunamis, floods, mudslides, and drought. Although earthquakes are not related to climate change, when participatory methodologies are developed, it is impossible to separate clearly different events, and disaster reduction policies in general embraces an all hazards approach. During the last earthquake and tsunami in Chile in 2010, preparedness was perceived as weak, generating a wide public discussion, which partially explains how this factor appeared relevant in workshops in Biobio and Metropolitan regions (earthquake covered the entire study area, but more intensely between Biobio and Metropolitan regions). Several studies 


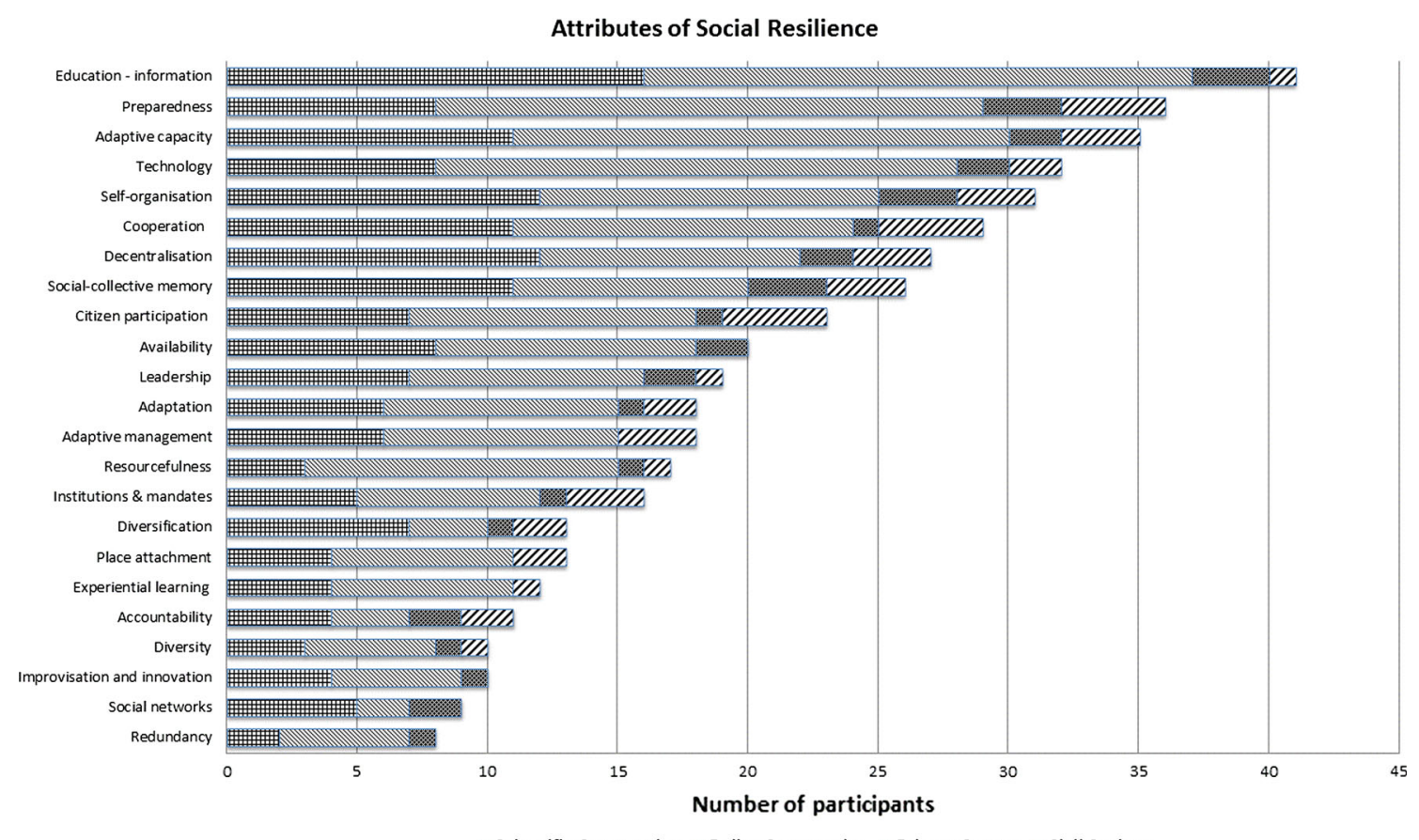

Scientific Community Policy Community

Fig. 5 Score of attributes of social resilience

have analysed the psychological impact of this earthquake (Gaborit 2010; Cova and Rincón 2010) and others have studied the slow action of the state (Acevedo 2013; Romero 2014). Uncertainty is a factor that affects psychologically due to lack of knowledge, while preparedness seeks to reduce this uncertainty (Naranjo Álvarez 2010; Mosquera and Gómez 2011).

The second part of the attributes' selection process was selecting the five most important attributes. This was done with the support of graphical representation afforded by the 'Resilience Wheel' by Aldunce et al. (2014b) (See Fig. 6), where all participants could see each other's selections and discuss their choices. Table 5 ranks selections made on the questionnaire and the wheel, in total and by region. In this table, it is possible to see the diversity of preferences between the first (individual) and second (with discussion) selection during workshops.

There are no apparent differences in the selections of the most important attribute, where 'Education-information' emerged as the most substantial aspect. Perhaps, Metropolitan region is highlighted, because initially participants considered 'Education-Information' in third place, however, in the second selection, this attribute was considered as first. This change can be partly explained by the fact that in this region, $73.7 \%$ of participants were from public sector, whose field of work is in planning and management. Therefore, the questionnaire collected individual preferences, and in general, these are associated with own ideas according to the performance area.
However, in the second selection, participants dialogued with other actors about their choices, reaching the same pattern as in the other regions. As van de Kerkhof and Wieczorek (2005) state, the transitional process of mutual learning requires that actors leave their own interests and ideas, opening their mind to other perspectives and information. Therefore, the group discussion allowed this transition between individual viewpoints to integrated ideas. This process can explain the importance of the attributes: 'cooperation' and 'citizen participation', during the second selection of attributes.

It is interesting to note the emergence of 'decentralisation' and the inclusion of 'political will'. With respect to decentralisation, Chile is a centralised country where the Metropolitan region is the political power, home to the leading national institutions, and where most important decisions are made. This situation has been claimed historically by citizen and politicians of other regions. Although there has been an effort to decentralise undertaken by the central government, for example, the creation of Los Ríos region in 2007, this effort is perceived as weak. Regions continue to demand more independence, considering this factor as determinant of their limited development (Montecinos 2005; Waissbluth et al. 2007). For this reason, it is not strange that this aspect will be important in Los Ríos and Biobío, but absent in the Metropolitan region.

Regarding 'political will', its inclusion in the Los Ríos workshop can be associated with 'decentralisation' and the perception of a lack of political will, in order to, achieve it. 
Fig. 6 Photographs of the selection of attribute on 'resilience wheel' in workshops (a, b)

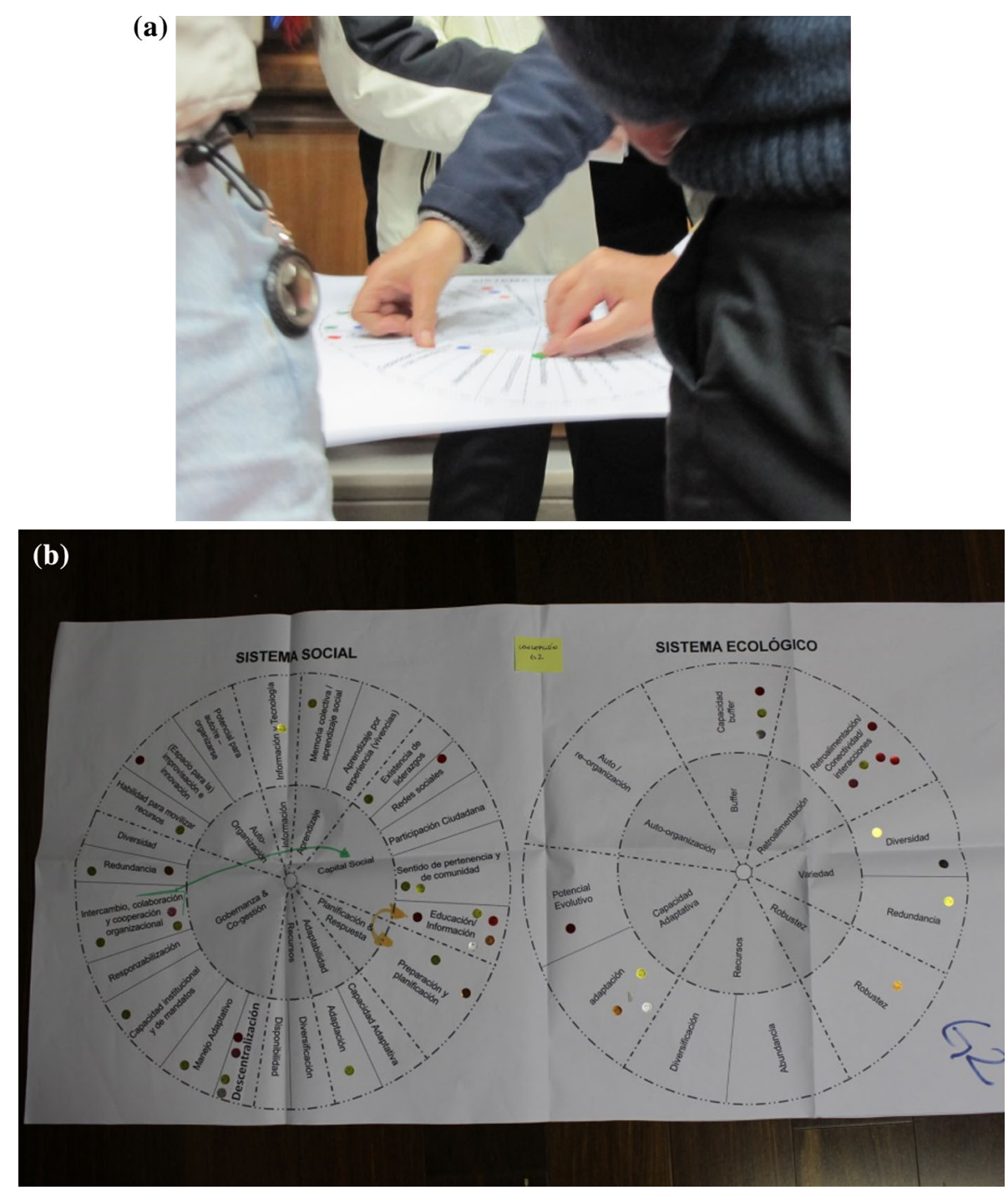

According to Waissbluth et al. (2007), Chilean political elites have historically considered that regions and municipalities do not have the capacity for managing greater responsibilities. Tagle (1985) argues that Chilean institutions are monopolised by politicians from the capital to the detriment of regional and local interests. This aspect allows us to connect the emergence of decentralisation and political will with the lack of territorialisation that, at the same time, could partially explain the lower participation rate of private sector and civil society.

'Preparedness', ‘education-information', 'decentralisation', and 'political will', among others, have important implications on governance, because these concepts are closely linked to proactivity, innovation, adaptation, awareness, warning, self-management, and training, promoting local responsibility and a more balanced decisionmaking (Aldunce et al. 2015). Therefore, they involve moving from the response or reactive resilience to proactive resilience, which some scholars argues is where societies should be moving towards (Aldunce et al. 2015; Handmer and Dovers 1996).

\section{General analysis}

Overall, there is no marked difference between regions, where issues of national interest, such as 'education-information' and 'preparedness', are highlighted over others. Given these results, it seems important to note the type of actor more so than the place where they live into a national context. This reinforces why special attention must be given to the different understandings in knowledge coproduction processes. However, regional and local aspects considered historically relevant, such as 'decentralisation' or 'political will', emerged as differentiators. In addition, to be involved in a discussion process, knowledge and mutual learning seem to have a high influence, generating a similar distribution of final responses and decreasing their diversity. This point should not be seen as negative, but as 
Table 5 Attributes of social resilience: comparative ranking between individual and selection in group

\begin{tabular}{|c|c|c|c|c|}
\hline & \multicolumn{2}{|l|}{ Total } & \multicolumn{2}{|l|}{ Valdivia } \\
\hline & Questionnaire & Wheel & Questionnaire & Wheel \\
\hline 1 & $\begin{array}{l}\text { Education- } \\
\text { information }\end{array}$ & $\begin{array}{l}\text { Education- } \\
\text { information }\end{array}$ & $\begin{array}{l}\text { Education- } \\
\text { information }\end{array}$ & $\begin{array}{l}\text { Education- } \\
\text { information }\end{array}$ \\
\hline 2 & Preparedness & Preparedness & Adaptive capacity & Technology \\
\hline 3 & Adaptive capacity & $\begin{array}{l}\text { Technology } \\
\text { Cooperation }\end{array}$ & Self-organisation & $\begin{array}{l}\text { Preparedness } \\
\text { Cooperation } \\
\text { Adaptive capacity }\end{array}$ \\
\hline \multirow[t]{3}{*}{4} & Technology & $\begin{array}{l}\text { Decentralisation } \\
\text { Citizen participation }\end{array}$ & Decentralisation & Political will \\
\hline & Concepcion & & Santiago & \\
\hline & Questionnaire & Wheel & Questionnaire & Wheel \\
\hline 1 & Education-information & $\begin{array}{l}\text { Education- } \\
\text { information }\end{array}$ & Preparedness & $\begin{array}{l}\text { Education-information } \\
\text { Preparedness }\end{array}$ \\
\hline 2 & $\begin{array}{l}\text { Preparedness } \\
\text { Decentralisation }\end{array}$ & $\begin{array}{l}\text { Place attachment } \\
\text { Decentralisation }\end{array}$ & $\begin{array}{l}\text { Adaptive capacity } \\
\text { Technology }\end{array}$ & $\begin{array}{l}\text { Technology } \\
\text { Cooperation }\end{array}$ \\
\hline 3 & $\begin{array}{l}\text { Technology } \\
\text { Self-organisation }\end{array}$ & Citizen participation & Education-information & $\begin{array}{l}\text { Institutions and } \\
\text { mandates }\end{array}$ \\
\hline 4 & $\begin{array}{l}\text { Leadership } \\
\text { Social-collective } \\
\text { memory } \\
\text { Cooperation }\end{array}$ & $\begin{array}{l}\text { Leadership } \\
\text { Preparedness } \\
\text { Accountability }\end{array}$ & $\begin{array}{l}\text { Cooperation } \\
\text { Institutions \& } \\
\text { mandates }\end{array}$ & $\begin{array}{l}\text { Leadership } \\
\text { Citizen participation } \\
\text { Place attachment } \\
\text { Adaptive management }\end{array}$ \\
\hline
\end{tabular}

a normal process of learning. Indeed, according to van de Kerkhof and Wieczorek (2005) and Pahl-Wostl et al. (2007), any kind of learning implies a change in actions or knowledge of who learns, capturing the core of social learning.

In the case study, where it was necessary to identify the understandings of resilience and its attributes among participants, the learning process led to consensus. However, caution should be exercised, because in other cases, it is deliberation rather than consensus that is desired, ideally improving the long-term contribution of stakeholders in policy processes (van de Kerkhof 2006).

The ethical dimension was fundamental in order to organise and perform our research. Principles included in Table 3 were the basis of this research, because our concern was to avoid false expectations (Singh et al. 2013a), respect different understandings (Warburton and Martin 1999), balance power relations between participants, and avoid treating communities as data extraction sources, called by Moodie (2010) as "helicopter research". In our view, not only do these aspects allow for trust in the research team, which is fundamental for achieving involvement and engagement, but also they must be considered the core of researchers' behaviour. In particular, power asymmetries were faced through individual questionnaires and discussion groups. The former allows us to have responses with the same weight/influence on the result. For discussion groups, recognising that power asymmetries cannot be fully placated, the role of facilitators was crucial. They were trained to face with it.

As Miller et al. (2010), p. 16 emphasise, "resilience research can help to design opportunities for reflection and learning, and appropriate networks, institutions, and governance structures". In this context, the diversity of meanings and understanding of resilience in the literature should be seen as an opportunity for the co-production of knowledge, because it allows us to build contextualised attributes, and their measures and strategies of application. Involving stakeholders in the design and decision process that frames their own development, generating the necessary engagement and empowerment in order to build and sustain long-term policy implementation (Wolf and Moser 2011).

In this study, we show how resilience theory can be articulated into practice, addressing 4 of the 5 "dimensions of knowledge co-production" raised by Armitage et al. (2011), p. 999: knowledge gathering through questionnaires; knowledge sharing through discussion groups; knowledge integration through discussion groups and plenary; and knowledge interpretation through the analysis 
and the discussion during the seminar of return results. In order to incorporate the knowledge application (fifth dimension), we consider that efforts for co-producing knowledge are linked to political decisions. By doing so, they have the potential first to institutionalise the process, giving support, continuity, and financing; second, it would approach territorial realities; and third, it would encourage participation and empowerment in different levels of governance.

Decentralisation as a political process and territorialisation as a socio-natural process seem to be key points in the development of this kind of work in order to move not only from theory to practice, but also towards real applicability, because the current context discourages the participation of local actors beyond public and academic sectors. Therefore, one of the challenges is to create bridges that increase motivation for participating.

The participation of scientists in the process was important. Regarding this participation, Blanco and Fuenzalida (2013) explain, one challenge for academia is to understand that we are not neutral entities generating pure information, supplemented by Cornell et al. (2013), p. 62 who argue that "it also requires an awareness and willingness on the part of the science community to accept this responsibility for transformation and engagement, while acknowledging the contested and political nature of responding to global change." The workshops conducted in this study gave a real opportunity for these scientists to engage with other actors in the process of co-producing knowledge.

\section{Conclusions}

Motivated by the clear need for concrete and demonstrable means of bringing theory to practice on issues of resilience through participatory processes, the research process in this study included: first, to take a systematic review on resilience to climate change; second, to carry out an actor search with an inclusive methodology that gathers up visions and perception through individual and discussion processes in order to analyse the theory; third, quantitative and qualitative instruments and ludic tools of works; fourth, to create the participation environment in workshops through training of facilitators; and finally, to analyse and generate a devolution process.

At least four lessons related to methods and approaches emerge from this knowledge co-production:

- This research demonstrates that theory can be articulated into practice through different instruments and tools if knowledge dimensions are considered.
- Principles and ethical dimension should be included from the design phase onward.

- The facilitator role is crucial, and therefore, protocol, guide of work, and training are fundamental.

- In the same vein that Armitage et al. (2011) identify, how to face differences in understanding, shared understanding, power relations, and normative context seems to be important challenges for the co-production of knowledge.

The applicability of this kind of process in other places can be achieved, but any process needs to be contextualised; therefore, first, the research team must know historical, social, environmental, political, and economic realities; second, language, tools, and provided information must allow participants to understand the process. If this aspect is not achieved; asymmetries are increased during the process.

From emerged results, key lessons can be considered for policy makers and society. First, when efforts for building resilience are made, understanding resilience as an ability or capacity gives the opportunity to focus on socio-ecological aspects. Second, the framing of resilience as a capacity not only 'to recovering', but also 'to adapt', 'to learn', 'to transform', and 'to re-organise', opens up opportunities to move towards continually improved systems. Third, equitable/universal access to information and education and to enhance preparedness emerged as key for building resilience, especially in countries frequently exposed to disasters related to climatic hazards.

Resilience and its diversity in meanings and understanding gave us an opportunity for co-producing knowledge, fulfilling the demand for the opening up of knowledge systems, with an intensification of relationship and collaboration between science and other actors, and an academic practice more oriented toward society. We find that it is relevant and pertinent to develop co-production processes in the context of resilience to climate change, because at least it allows us to communicate resilience from contextualised realities and languages, facilitating the engagement and trust of stakeholders, and establishing the legitimacy of the process.

However, based on our experience in this study, it is important to understand that this kind of effort is best served through permanent or more sustained efforts in collaboration with society. Furthermore, we consider that an explicit link to political decisions and context could facilitate institutionalised continuity and financial prioritisation; however, this remains to be affirmed through follow-up studies on ex-post policy evaluations. In our case, contextualisation to local realities could also empower processes to facilitate more meaningful decentralisation of decisions as a political process. In the Chilean context, 
these seem to be key points of consideration in the development of this kind of work. Many challenges remain, including how to generate regular dialogue and engagement between science, government, and society, where scientists assume part of the responsibility for transformation and engagement as an actor (at the same level of the others), making their own research open to public scrutiny, and to develop transdisciplinary work in order to enrich the research process and contextualise it.

Acknowledgments This publication also received the support of and is a contribution to the Center Resilience and Climate Research CR2 FONDAP \#1511009 and to the project FONDECYT No. 11140394. We thank the participants of the three workshops and their generosity and willingness to participate. We would also like to acknowledge and thank the three anonymous reviewers for their constructive feedback and comments for improving this manuscript.

Open Access This article is distributed under the terms of the Creative Commons Attribution 4.0 International License (http://crea tivecommons.org/licenses/by/4.0/), which permits unrestricted use, distribution, and reproduction in any medium, provided you give appropriate credit to the original author(s) and the source, provide a link to the Creative Commons license, and indicate if changes were made.

\section{References}

Acevedo J (2013) Chile, Haití, Christchurch y Katrina: una aproximación a un análisis contrafactual [Chile, Haití, Christchurch and Katrina: an approach to counterfactual analysis]. Revista Ciencia y Tecnología 12:43-56

Adler CE, Aldunce P, Indvik K, Alegría D, Borquez R, Galaz V (2015) Resilience. In: Bäckstrand K, Lövbrand E (eds) Research handbook on climate governance. Edward Elgar Publishing, Cheltenham, UK, pp 491-502

Aldunce P, Beilin R, Handmer J, Howden M (2014a) Framing disaster resilience: the implications of the diverse conceptualisations of "bouncing back". Disaster Prev Manag 23:252-270

Aldunce P, Indvik K, Borquez R, Adler C, Galaz V (2014b) Resilience in the context of climate change: a systematic review of the literature to aid a navigation of diversity. Center for Climate and Resilience Research, University of Chile, Santiago

Aldunce P, Beilin R, Howden M, Handmer J (2015) Resilience for disaster risk management in a changing climate: practitioners' frames and practices. Glob Environ Change-Hum Policy Dimens 30:1-11

Aldunce P, Handmer J, Beilin R, Howden M (2016) Is climate change framed as 'business as usual'or as a challenging issue? The practitioners' dilemma. Environ Plan C Gov Policy 34(5):999-1019

Armitage D, Marschke M, Plummer R (2008) Adaptive co-management and the paradox of learning. Glob Environ Change 18:86-98

Armitage D, Berkes F, Dale A, Kocho-Schellenberg E, Patton E (2011) Co-management and the co-production of knowledge: learning to adapt in Canada's Arctic. Glob Environ Change 21:995-1004

Biblioteca del Congreso Nacional (BCN) (2016) Chile nuestro país [Chile our country]. In: Biblioteca del Congreso Nacional. http:// siit2.bcn.cl/nuestropais/regiones. Accessed 22 Jan 2016

Berkes F (2007) Understanding uncertainty and reducing vulnerability: lessons from resilience thinking. Nat Hazards 41:283-295
Berrang-Ford L, Ford JD, Paterson J (2011) Are we adapting to climate change? Glob Environ Change 21:25-33

Blaikie P, Brown K, Stocking M, Tang L, Dixon P, Sillitoe P (1997) Knowledge in action: local knowledge as a development resource and barriers to its incorporation in natural resource research and development. Agric Syst 55:217-237

Blanco G, Fuenzalida MI (2013) La construcción de agendas científicas sobre cambio climático y su influencia en la territorialización de políticas públicas: reflexiones a partir del caso chileno [Construction of scientific agendas on climate change and its influence on territorialization of public policies: reflections from the Chilean case]. In: Postigo J (ed) Cambio climático, movimientos sociales y políticas públicas. Una vinculación necesaria. Consejo Latinoamericano de Ciencias Sociales (CLACSO). Santiago, Chile. Instituto de Ciencias Alejandro Lipschutz (ICAL), Santiago de Chile, pp 75-102

Boyatzis RE (1998) Transforming qualitative information: thematic analysis and code development. Sage, New York

Brandt P, Ernst A, Gralla F, Luederitz C, Lang DJ, Newig J, Reinert F, Abson DJ, von Wehrden H (2013) A review of transdisciplinary research in sustainability science. Ecol Econ 92:1-15

Cabalin C (2012) Neoliberal education and student movements in Chile: inequalities and malaise. Policy Futures Educ 10:219-228

Cash DW, Clark WC, Alcock F, Dickson NM, Eckley N, Guston DH, Jäger J, Mitchell RB (2003) Knowledge systems for sustainable development. Proc Natl Acad Sci 100:8086-8091

Cornell S, Berkhout F, Tuinstra W, Tàbara JD, Jäger J, Chabay I, de Wit B, Langlais R, Mills D, Moll P (2013) Opening up knowledge systems for better responses to global environmental change. Environ Sci Policy 28:60-70

Cova F, Rincón P (2010) El terremoto y tsunami del 27-F y sus efectos en la salud mental $[27 \mathrm{~F}$ earthquake and tsunami and its mental heath effects]. Terapia Psicológica 28:179-185

Djalante R, Thomalla F (2010) Community resilience to natural hazards and climate change: a review of definitions and operational frameworks. Asian J Environ Disaster Manag 3:3

Downes BJ, Miller F, Barnett J, Glaister A, Ellemor H (2013) How do we know about resilience? An analysis of empirical research on resilience, and implications for interdisciplinary praxis. Environ Res Lett 8:014041

Fleet N (2011) Movimiento estudiantil y transformaciones sociales en Chile: una perspectiva sociológica [Student movement and social transformations in Chile: a sociological perspectiva]. Polis (Santiago) 10:99-116

Folke C (2006) Resilience: the emergence of a perspective for socialecological systems analyses. Glob Environ Change 16:253-267

Gaborit M (2010) Desatres y trauma psicologico. Pensamiento psicológico, 2

Garreaud R (2011) Cambio Climático: bases físicas e impactos en Chile. Revista Tierra Adentro-INIA 93:13-19

Gero A, Méheux K, Dominey-Howes D (2011) Integrating community based disaster risk reduction and climate change adaptation: examples from the Pacific. Nat Hazards Earth Syst Sci 11:101-113

Gibbons M (1999) Science's new social contract with society. Nature 402:C81-C84

Handmer JW, Dovers SR (1996) A typology of resilience: rethinking institutions for sustainable development. Org Environ 9:482-511

Ilustre Municipalidad de Valdivia (2016) Clima y vegetation [Climate and vegetation]. http://www.munivaldivia.cl/www/municipal_ valdivia/index.php?option $=$ com_content $\&$ view $=$ article $\& i d=1391$ \&Itemid=804\&lang=es. Accessed 22 Jan 2016

Instituto Nacional de Estadística (INE) (ed) (2010) Síntesis geográfica regional, compendio estadístico 2010 [Regional geographic synthesis, statistical compendium 2010] 
Instituto Nacional de Estadística (INE) (ed) (2012) Síntesis geográfica regional, compendio estadístico 2012 [Regional geographic synthesis, statistical compendium 2014]. http://www.ine.cl/ canales/menu/publicaciones/compendio_estadistico/compendio_ estadistico2012.php. Accessed 22 Jan 2016

Instituto Nacional de Estadística (INE) (ed) (2014) Síntesis geográfica regional, compendio estadístico 2014 [Regional geographic synthesis, statistical compendium 2014]. http://www.ine.cl/ canales/menu/publicaciones/calendario_de_publicaciones/pdf/ compendio_2014.pdf. Accessed 22 Jan 2016

LaVeaux D, Christopher S (2009) Contextualizing CBPR: key principles of CBPR meet the Indigenous research context. Pimatisiwin $7: 1$

Mackey A, Gass SM (2015) Second language research: methodology and design. Routledge, London

Maxwell S (2009) Eliminating world poverty: building our common future. Dev Policy Rev 27:767-770

Meza L, Corso S, Soza S, Hammarskjöld AD, de Estudios O, Agrarias-ODEPA P (2010) Gestión del riesgo de sequía y otros eventos climáticos extremos en Chile [Risk management to drought and other climatic events in Chile]. Organización de las Naciones Unidas para la Agricultura y la Alimentación (FAO), Rome

Miller TR, Baird TD, Littlefield CM, Kofinas G, Chapin FS III, Redman CL (2008) Epistemological pluralism: reorganizing interdisciplinary research. Ecol Soc 13:46

Miller F, Osbahr H, Boyd E, Thomalla F, Bharwani S, Ziervogel G, Walker B, Birkmann J, van der Leeuw S, Rockstrom J, Hinkel J, Downing T, Folke C, Nelson D (2010) Resilience and vulnerability: complementary or conflicting concepts? Ecol Soc $15: 1-25$

Montecinos E (2005) Antecedentes sobre la relación histórica centralismo y descentralización en Chile [Background on the historical relationship between centralism and decentralization in Chile]. Revista Venezolana de Gerencia, 10

Moodie S (2010) Power, rights, respect and data ownership in academic research with indigenous peoples. Environ Res 110:818-820

Mosquera J, Gómez E (2011) La gestión del riesgo-de la incertidumbre a la adaptibilidad. Bistua Revista de LA Facultad de Ciencias Basicas, 9

Naranjo Álvarez RJ (2010) Neurología de la resiliencia y desastres [Neurology od resilience and disasters]. Revista Cubana de Salud Pública 36:270-274

Nelson DR, Adger WN, Brown K (2007) Adaptation to environmental change: contributions of a resilience framework. Annu Rev Environ Resour 32:395-419

O'Brien G, O'Keefe P, Gadema Z, Swords J (2010) Approaching disaster management through social learning. Disaster Prev Manag Int J 19:498-508

Olwig MF (2012) Multi-sited resilience: the mutual construction of "local" and "global" understandings and practices of adaptation and innovation. Appl Geogr 33:112-118

Pahl-Wostl C, Craps M, Dewulf A, Mostert E, Tabara D, Taillieu T (2007) Social learning and water resources management. Ecol Soc 12(2): 2007

Pelling M (2011) Adapting to climate change, from resilience to adaptation. Routledge, New York
Pohl C, Hirsch Hadorn G (2007) Principles for designing transciplinary research, proposed by the Swiss academies of arts and sciences. Oekom, München

Pohl C, Rist S, Zimmermann A, Fry P, Gurung GS, Schneider F, Speranza CI, Kiteme B, Boillat S, Serrano E (2010) Researchers' roles in knowledge co-production: experience from sustainability research in Kenya, Switzerland, Bolivia and Nepal. Sci Public Policy 37:267-281

Romero H (2014) Vulnerabilidad, resiliencia y ordenamiento territorial de los desastres socionaturales en Chile [Vulnerability, resilience and spatial planning of the socialnatural disasters in Chile]. Polígonos Revista de Geografía 26:87-110

Singh RK, Turner NJ, Pandey C (2012) "Tinni" Rice (Oryza rufipogon Griff.) production: an integrated sociocultural agroecosystem in Eastern Uttar Pradesh of India. Environ Manag 49:26-43

Singh R, Singh K, Turner N (2013a) A special note on Prior Informed Consent (PIC). Why are you asking our gyan (knowledge) and padhati (practice)?: ethics and prior informed consent for research on traditional knowledge systems. Indian $\mathrm{J}$ Tradit Knowl 12:547-562

Singh RK, Rallen O, Padung E (2013b) Elderly Adi Women of Arunachal Pradesh: "living encyclopedias" and cultural refugia in biodiversity conservation of the Eastern Himalaya, India. Environ Manag 52:712-735

Tagle M (1985) Notas históricas sobre el centralismo institucional chileno. EURE Revista Latinoamericana de Estudios Urbano Regionales 12:163

Thomalla F, Larsen RK (2010) Resilience in the context of tsunami early warning systems and community disaster preparedness in the Indian Ocean region. Environ Hazards 9:249-265

van de Kerkhof M (2006) Making a difference: on the constraints of consensus building and the relevance of deliberation in stakeholder dialogues. Policy Sci 39:279-299

van de Kerkhof M, Wieczorek A (2005) Learning and stakeholder participation in transition processes towards sustainability: methodological considerations. Technol Forecast Soc Chang 72:733-747

Vogel C, Moser SC, Kasperson RE, Dabelko GD (2007) Linking vulnerability, adaptation, and resilience science to practice: pathways, players, and partnerships. Glob Environ Change 17:349-364

Waissbluth M, Leyton C, Inostroza J (2007) La descentralización en Chile 1990-2005: asignatura pendiente [Decentralization in Chile 1990-2005: unfinished]. Revista del CLAD Reforma y Democracia 37:1-11

Walker B, Salt D (2006) Resilience thinking: how can landscapes and communities absorb disturbance and maintain function?. Island Press, Washington, DC

Warburton H, Martin A (1999) Local people's knowledge in natural resources research. Socio-econ Methodol Nat Resour Res

Wildavsky A (1988) Search for safety. Transaction Books, New Brunswick

Wolf J, Moser SC (2011) Individual understandings, perceptions, and engagement with climate change: insights from in-depth studies across the world. Wiley Interdiscip Rev Clim Change 2:547-569 